\title{
Success predictors of village financial systems
}

\author{
Dewa Ayu Eny Wulandari ${ }^{a^{*}}$,Herkulanus Bambang Suprasto ${ }^{a}$, A.A.N.B. Dwirandra ${ }^{a}$ and Ida Bagus \\ Putra Astika ${ }^{a}$
}

\begin{abstract}
${ }^{a}$ Economics and Business Faculty, Udayana University, Bali, Indonesia
\section{H R O N I C L E}

Article history:

Received: February 27, 2021

Received in revised format:

April 292021

Accepted: May 21, 2021

Available online:

May 21, 2021

Keywords:

System Quality

Information Quality

Service Quality

Quality of Human Resource

Use

User Satisfaction

Net Benefits

\section{A B S T R A C T}

SISKEUDES is a financial system used by the village government aimed at improving accountability, creating common perceptions in the delivery and application of various laws and regulations in the form of village financial management systems and procedures. Implementation of SISKEUDES helps us improve good corporate governance of village government in Indonesia. However, in the Village Assistance Report in Badung Regency in 2018 and 2019, there were input errors from planning, budgeting, administration and financial reporting. Based on this phenomenon, this study tested the predictor of successful application of the system. The measurement of SISKEUDES success is based on DeLone and McLean information system success model. This study examines the direct effect of system quality, information quality, service quality and quality of human resource on use, user satisfaction and net benefits. The sample determination technique uses purposive sampling with criteria of all SISKEUDES users in Badung Regency Village Government with a minimum of 1 year working experience. Data analysis uses Partial Least Square with SmartPLS 3. The results show that only system quality, information quality, and service quality have positive effects on user satisfaction, while the quality of human resources has no effect on user satisfaction. The quality of information, the quality of service, and the quality of human resources have positive effects on the use, while the quality of the system has no effect on the use. The quality of information, service quality, use and user satisfaction have positive effects on net benefits.
\end{abstract}

\section{Introduction}

The Village Government is given the right to village autonomy to manage all development affairs in the Village by itself. Providing funds to village governments is prone to corruption and financial administrative errors. The BPKP (provincial audit board) in 2015 found 15,100 potential errors and weaknesses in the accountability of village funds. Therefore, the BPKP and the Ministry of Home Affairs have launched a special financial management system for the Village Government, namely the Village Financial System (SISKEUDES) which was implemented in 2016. Badung Regency is one of the areas where the Village Government has entirely implemented the Village Financial System (SISKEUDES). This system includes planning, budgeting, administration, and reporting of all funds managed by the Village Government. After implementing this information system for daily activities in village financial management in the hope of being able to present accountable financial reports. SISKEUDES is aimed at increasing shared perceptions in the delivery and application of various laws and regulations in the form of village financial management systems and procedures. Since the implementation of SISKEUDES, the level of good village government management in Indonesia has increased every year. This is also followed by an increase in village funds every year. The large amount of village funds managed, especially in Badung, demands to generate * Corresponding author.

E-mail address: ayueny12@gmail.com (D. A. E. Wulandari)

(C) 2021 by the authors; licensee Growing Science, Canada doi: 10.5267/j.ac.2021.5.012 
accountability in the form of reports that are accountable, transparent, and in accordance with applicable regulations. In the Village Assistance Report in Badung Regency, there are still errors in input from planning, budgeting, administering village finances. In addition, there are still villages that deposit incomplete accountability documents. This makes the reason whether the implementation of SISKEUDES in Badung has been optimally used and the purpose of having SISKEUDES is achieved. The model used is a modified DeLone and McLean (2003) by adding a variable to the quality of human resources from system users so that the system is suitable for implementation in the village government. The general objective of this study is to test and develop the village financial system (Siskeudes) with reference to the modified McLean and DeLone model (2003). This system is mandatory, but a person's behavior to use the mandatory system can be explained by Theory Planned of Behavior (TPB) (Prianto, 2014). TPB explains that a person will carry out an action or something driven by behavioral beliefs, normative beliefs, and control beliefs. After a system is implemented, a post-implementation review can be carried out, which is a comprehensive predictor of a new system that is carried out after implementation in order to determine whether the system has operated as expected and whether it has met or satisfied user needs (Perry, 2006 ). Net benefits will be felt by users when the system is used repeatedly and feel satisfied with the system. DeLone and McLean (2016) state that the use of systems is the main focus in measuring the success of implementing a system. In addition, information system end user satisfaction can be used as a measure of the success of an information system (Doll and Torkzadeh, 1988).DeLone and McLean (1992) explain that the higher the quality of the system and the more optimal the system is used, the system users will often use the system and will be satisfied. In addition, one of the main motivations of using information system applications is to provide users with accurate, timely, and relevant information (DeLone and McLean, 2016). Therefore, information quality is also an important factor in contributing to user satisfaction, but it should be treated as a separate measure of success from the enduser satisfaction instrument (Doll et al. 1994). Tilahun (2019) states that the quality of human resources is one of the main factors affecting the choice of implementing an accounting information system. Therefore, the higher the personal technical skills of the accounting information system, the better the accounting information system performance will be and have an impact on better organizational performance (Jin, 2002). So that the conceptual framework of this research can be formulated as Fig. 1 and the hypothesis of this study.

$\mathbf{H}_{1}$ : System quality has a positive effect on Use.

H2: System quality has a positive effect on user satisfaction.

$\mathbf{H}_{3}$ : System quality has a positive effect on Net Benefit.

$\mathbf{H}_{4}$ : Information quality has a positive effect on Use.

H5: The quality of information has an effect on user satisfaction.

$\mathbf{H}_{6}$ : Information quality has a positive effect on net benefits.

$\mathbf{H}_{7}$ : Service quality has a positive effect on Use.

$\mathbf{H}_{8}$ : Service quality has a positive effect on user satisfaction.

H9: Service quality has a positive effect on net benefits.

H10: The quality of human resources has a positive effect on Use.

$\mathbf{H}_{11}$ : The quality of human resources has an effect on user satisfaction.

$\mathbf{H}_{12}$ : The quality of human resources has a positive effect on net benefits.

H13: Use has a positive effect on Net Benefit.

H14: User Satisfaction has a positive effect on Net Benefits.

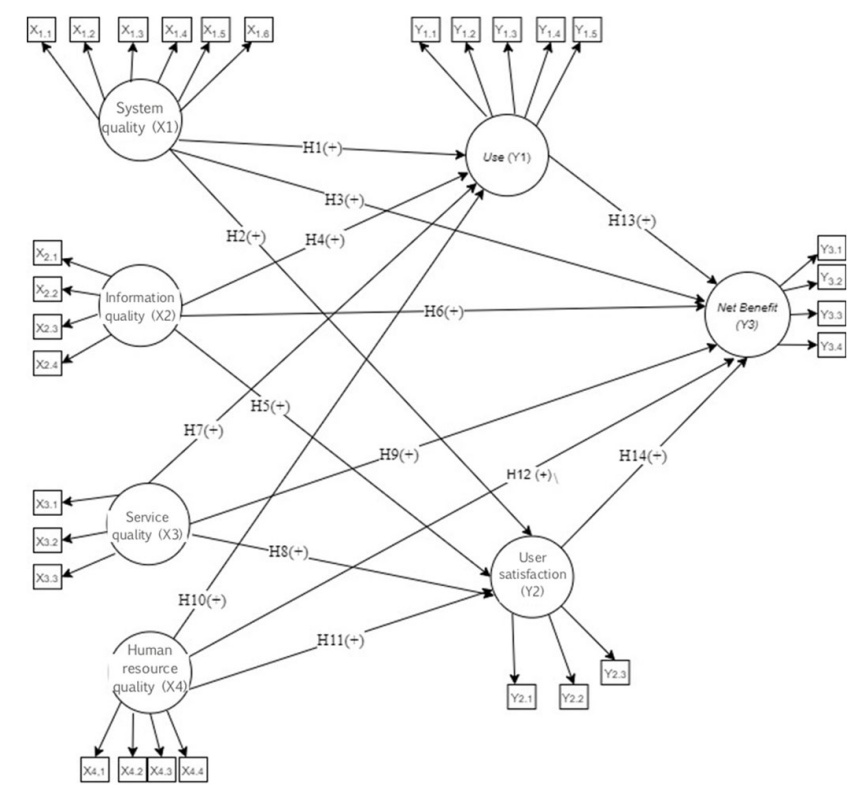

Fig. 1. The proposed study of the paper 


\section{Research methods}

This research was conducted in the village government in Badung Regency. The total number of villages in Badung Regency is 46 villages in 5 districts, namely, Mengwi District, Abiansemal District, Petang District, North Kuta District, and South Kuta District. Villages in Badung are the research locations because the villages in Badung have quite high managed funds of around Rp. 11 billion to Rp. 23 billion per village. In addition, Village Original Income in Badung is the highest in Bali. All villages in Badung have also implemented Siskeudes from the beginning of the launch of this application, seen from the memorandum of outstanding signed by the Badung Regent and BPKP Bali Representative on March 4, 2016. The data collection method used is a survey method with a questionnaire technique. Determination of the research sample using nonprobability sampling technique with purposive sampling. Samples were taken based on the criteria of the financial manager's duties in the Minister of Home Affairs Regulation (Permendagri) No. 20 of 2018 concerning Village Financial Management. Therefore, the selected sample includes the head of financial affairs as well as operators of the siskeudes in Badung Regency and has served at least one year so that it is assumed that they are able to and receive the benefits of using the siskeudes. The research hypothesis testing was carried out by using the Structural Equation Model (SEM) approach based on Partial Least Square (PLS).

\section{Results and discussion}

Respondent characteristic data used in this study include age and last education. Based on the data on the characteristics of the respondents, it is described as follows: Age is used to determine the age distribution of the respondent's financial management employees who are the samples in this study. This study divides age based on generations, namely generation $\mathrm{X}$ and generation Y (Milineal). Generation X with the birth year range 1965-1980 as many as 31 people (38.75\%) in this study. Generation Y with a birth range around the beginning of 1981-1996 as many as 49 people (61.25\%). This means that the majority of Financial Management Employees who are sampled in this study are respondents belonging to the $\mathrm{Y}$ generation or the millennial generation. The millennial generation is a generation born during rapid technological advances (Yuswohady, 2016). Since birth, this generation has been accompanied, learned, and interacted with digital devices. Therefore, the characteristics of the respondents in this study illustrate that most village officials tend to be accustomed to using technology so that SISKUEDES can be implemented properly. The last level of education is used as an indicator to determine the intellectual level of respondents who are involved in financial management of villages in Badung district. The highest percentage of education level involved in financial management of villages in Badung district is at the D4 / S1 education level as many as 41 people $(51.25 \%)$ and the lowest percentage is for the level of education involved in management. village finance in Badung district is the education level of D1 and PGA Guru, namely 1 person (1.25\%) each. This shows that the majority of respondents, namely village financial managers, have an education level of D4 / S1, so it can be said that village financial managers already have adequate intellectual / education to manage village finances.

\section{Table 1}

R-square and Q-square test results

\begin{tabular}{lcc}
\hline & $\mathrm{R}-$ square & $\mathrm{R}-$ Square - Adjusted \\
\hline Use $\left(\mathrm{Y}_{1}\right)$ & 0.681 & 0.664 \\
User Satisfaction $\left(\mathrm{Y}_{2}\right)$ & 0.721 & 0.706 \\
Net Benefit $\left(\mathrm{Y}_{3}\right)$ & 0.838 & 0.825 \\
\hline Calculation: $\mathrm{Q}^{2}=1-\left(1-\left(\mathrm{R}_{1}{ }^{2}\right)\right)\left(1-\left(\mathrm{R}_{2}{ }^{2}\right)\right)=1-(1-0.664)(1-0.706)(1-0.825)=0.983$ & \\
\hline
\end{tabular}

Calculation: $\mathrm{Q}^{2}=1-\left(1-\left(\mathrm{R}_{1}{ }^{2}\right)\right)(1-(\mathrm{R}$

Based on Table 1, it can be seen that the value of Adjusted R Square Y1 is 0.641 which means that 64.1 percent of the variation in the use of SISKEUDES in this study can be explained by the variables of system quality, information quality, service quality, and human resource quality. While the remaining 35.9 percent is influenced by other variables outside of the model used in this study. The value of Adjusted R Square Y2 is 0.706 which means that 70.6 percent of the variation in SISKEUDES user satisfaction in this study can be explained by the variables of system quality, information quality, service quality, and human resource quality. While the remaining 29.4 percent is influenced by other variables outside of the model used in this study. The value of Adjusted R Square Y3 is 0.825 which means that 82.5 percent of the variation in the net benefit of SISKEUDES in this study can be explained by the variables of system quality, information quality, service quality, human resource quality, use, and user satisfaction. While the remaining 17.5 percent is influenced by other variables outside of the model used in this study. The direct effect test is carried out by paying attention to $\mathrm{p}$ values with an error rate of $1 \%, 5 \%$, and $10 \%$ in the bootstrapping calculation results. The results of the direct effect test are presented in Table 2.

\subsection{Effect of System Quality on Use}

The system quality variable has a negative path coefficient of -0.031 with a p value of 0.420 ( $p$ value $>0.10)$ which means that the first hypothesis (H2) is rejected. This proves that the quality of SISKEUDES has no effect on the use of SISKEUDES users in the Village Government in Badung. Village officials perceive that the use of SISKEUDES does not see the quality of the system. This is because the system is mandatory so that when the system is difficult to use and difficult to learn, users will still use the system to carry out the administration of village financial management. 
Based on the respondents' perceptions from the questionnaires distributed in this study, it can be seen that the lowest quality indicator of SISKEUDES is that the system is less stable and still frequently experiences damage. Therefore, village managers can only wait for the system to return to use when the system or system support components are damaged. The perception of the quality of the system in this study was not able to influence the increasing interest in the use of SISKEUDES. The results of this study are in line with the research of Rai and Suardikha (2019) who found there was no influence between system quality and the use of the SIKPD application in Buleleng Regency. Lestari and Soesanto (2020) found that system quality, especially the indicator of ease of use of the system, was unable to influence behavior to use the Streaming Video on Demand (SVOD) system in Indonesia. Sorongan and Qory (2020) also found that the quality of the E-Government system in Balikpapan was unable to influence user actions to use the system.

Table 2

Direct Effects Testing Results

\begin{tabular}{|c|c|c|c|c|c|}
\hline No & Influence between variables & $\begin{array}{c}\text { Path Coef. } \\
\text { (Bootstrapping) }\end{array}$ & $\begin{array}{c}p \\
\text { values }\end{array}$ & T Statistik & Information \\
\hline 1 & Quality System (X1) $\rightarrow$ Use (Y1) & $-0,031$ & 0,420 & 0,212 & $\mathrm{H}_{1}$ is rejected \\
\hline 2 & System Quality (X1) $\rightarrow$ User Satisfaction (Y2) & 0,202 & $0,047 * *$ & 1,673 & $\mathrm{H}_{2}$ is accepted \\
\hline 3 & System Quality (X1) $\rightarrow$ Net Benefits (Y3) & 0,023 & 0,214 & 0,203 & $\mathrm{H}_{3}$ rejected \\
\hline 4 & Information Quality (X2) $\rightarrow$ Use (Y1) & 0,380 & $0,016^{* *}$ & 2,151 & $\mathrm{H}_{4}$ accepted \\
\hline 5 & Information Quality (X2) $\rightarrow$ User Satisfaction (Y2) & 0,409 & $0,001 * * *$ & 3,007 & $\mathrm{H}_{5}$ is accepted \\
\hline 6 & Information Quality (X2) $\rightarrow$ Net Benefits (Y3) & 0,364 & $0,000 * * *$ & 3,402 & $\mathrm{H}_{6}$ accepted \\
\hline 7 & Quality of Service (X3) $\rightarrow$ Use (Y1) & 0,296 & $0,028 * *$ & 1,920 & $\mathrm{H}_{7}$ accepted \\
\hline 8 & Service Quality (X3) $\rightarrow$ User Satisfaction (Y2) & 0,308 & $0,002 * * *$ & 2,906 & $\mathrm{H}_{8}$ accepted \\
\hline 9 & Quality of Service (X3) $\rightarrow$ Net Benefits (Y3) & 0,186 & $0,035^{* *}$ & 1,810 & $\mathrm{H}_{9}$ is accepted \\
\hline 10 & HR Quality (X4) $\rightarrow$ Use (Y1) & 0,289 & $0,002 * * *$ & 2,880 & $\mathrm{H}_{10}$ accepted \\
\hline 11 & HR Quality (X4) $\rightarrow$ User Satisfaction (Y2) & $-0,018$ & 0,419 & 0,204 & $\mathrm{H}_{11}$ rejected \\
\hline 12 & HR Quality (X4) $\rightarrow$ Net Benefits (Y3) & 0,021 & 0,375 & 0,318 & $\mathrm{H}_{12}$ is rejected \\
\hline 13 & Use (Y1) $\rightarrow$ Net Benefits (Y3) & 0,271 & $0,003 * * *$ & 2,819 & $\mathrm{H}_{13}$ is accepted \\
\hline 14 & User Satisfaction (Y2) $\rightarrow$ Net Benefits (Y3) & 0,142 & $0,016^{* *}$ & 2,146 & $\mathrm{H}_{14}$ is accepted \\
\hline
\end{tabular}

Note: $*$ p-value $<0.1 ; * *$ p-value $<0.05 ; * * *$ p-value $<0.01$

Source: Processed data, 2021

\subsection{Effect of System Quality on User Satisfaction}

The system quality variable has a positive path coefficient of 0.202 with a $p$ value of 0.047 ( $p$ value $<0.05$ ), which means that the second hypothesis (H2) is accepted. This proves that the system quality of SISKUEDES has a positive effect on SISKEUDES user satisfaction in the village government in Badung. The positive path coefficient means that the better the quality of the system from SISKEUDES, the higher the user satisfaction in using SISKEUDES. Respondents' perceptions of the quality of SISKEUDES indicate that the system is easy to use, easy to learn, flexible, data is guaranteed safe, is easily accessed quickly and is integrated with other financial systems. This can be seen from the answers to the questionnaire of respondents who majority agree that the system can be accessed quickly and is easy to use. SISKEUDES also provides a menu related to village income bookkeeping, village expenditure and tax collection bookkeeping which is directly compiled into village financial reports so that the design of this system is deemed capable of providing what financial managers need. Therefore, SISKEUDES users find it more effective and efficient when using the system. SISKEUDES is perceived to be able to provide a sense of satisfaction to user needs. Based on the characteristics of the respondents studied, most of the respondents had the latest education level of S1. This reflects that most respondents have a fairly good competency in the use of information technology, so that when required to use SISKEUDES, SISKEUDES users tend to feel satisfied, because respondents find it easy to learn and use SISKEUDES. The results of this study are in line with research by Anggreni, et al (2020) which found that the quality of the SISKEUDES used in the SARBAGITA area was able to increase user satisfaction. The results of this study are in line with research by Anggreni et al. (2020) which found that the quality of the SISKEUDES used in the SARBAGITA area was able to increase user satisfaction. Research by Veeramootoo et al. (2018) found that system quality is able to affect the satisfaction of system users using internet access. System users will feel disappointed / dissatisfied when using the system, especially the online system, experiencing very long system access. Lee and Yu (2020) also found that the quality of the Learning Management Systems (LMS) system in Malaysia and in Korea was able to increase student satisfaction because the system was well designed and easy to use and accessed quickly.

\subsection{Effect of System Quality on Net Benefit}

The system quality variable has a positive path coefficient of 0.023 with a $p$ value of 0.214 ( $p$ value $<0.05$ ), which means that the third hypothesis (H3) is rejected. This proves that the quality of the SISKUEDES system has no effect on the net benefits of SISKEUDES in the village government in Badung. The perceived quality of SISKEUDES has not been able to provide direct net benefits to employee performance and village government performance. This is because even though they have used the system, village government employees still have to report directly to the Village Community Empowerment Service (DPMD) and the Inspectorate of Badung Regency regarding quarterly, semester, and annual reports. This is why the net benefit is still not directly felt by users. In accordance with the results of respondents' answers in this study, the lowest average for the net benefit variable is that they are still ineffective at work when using SISKEUDES. The results of this study are supported by Salam (2017), which found that the quality of the E-Village Budgeting system does not have a direct effect on 
the benefits felt by system users. This is because the system is not yet fully able to reduce operational costs and performance productivity is hampered due to the long response time to inputted data. Martin, et al. (2018) also found that the quality of the system was not able to directly influence the net benefits felt by users of the education information system in Portugal.

\subsection{Effect of Information Quality on Use}

The information quality variable has a positive path coefficient of 0.380 with a p value of 0.016 ( $p$ value $<0.05$ ), which means that the fourth hypothesis (H4) is accepted. This proves that the quality of information generated by SISKEUDES has a positive effect on use. The positive path coefficient means that the better the information generated by SISKEUDES, the more perceptions of using the system will be. SISKEUDES produces information in the form of reports (outputs) at the planning, budgeting, administration, bookkeeping, and reporting stages according to Permendagri Number 20 of 2018 and PMK 50 / PMK.07 / 2020 regarding the management of village funds, so that the resulting report and its information are more detailed, even down to the details for reports related to taxes and realization of activities (Rakhmawati \& Siti, 2020). The quality of information that is in accordance with user needs can increase the intensity of using SISKEUDES. The more fulfilled the user's needs for the information generated by SISKEUDES, the more the use of the system will increase. The results of this study are in line with the research of Purwanto and Suharno (2017) and Martono et al. (2020) who found that the quality of information is the most significant factor in increasing the intention to use information technology for users in an online environment. Noviyanti (2016) also found that the quality of information generated by SAIBA is in accordance with user needs so that it is a strong reason for users to use this information system.

\subsection{Effect of Information Quality on User Satisfaction}

The information quality variable has a positive path coefficient of 0.409 with a p value of 0.001 ( $p$ value $<0.01)$ and which means that the fifth hypothesis (H5) is accepted. This proves that the quality of information has a positive effect on user satisfaction. The positive path coefficient means that the better the quality of information generated from SISKEUDES, the greater the usage satisfaction felt by SISKEUDES users. SISKEUDES is designed to produce information that makes it easier for village officials to plan, budget, manage and report accountability for activities in the Village Government in accordance with the format of Permendagri No. 20 of 2018 concerning Village Financial Management. This quality financial information is expected to be a solution in order to increase village financial accountability. SISKEUDES is also very helpful for respondents, especially the village finance chief in the financial management process and can produce financial reports according to the specified time. Starting from inputting village planning, APB Desa budgeting, village administration, to village reporting and accountability can be done with one initial input so that it becomes efficient and effective for village performance. The quality of the information produced is also able to meet the needs of village financial managers, so that SISKEUDES users are satisfied using the system to carry out their work. The results of this study are also in line with Dirgantari et al. (2020) who found that the quality of information has the most dominant influence on user satisfaction because the quality of information is related to the delivery of information that must be conveyed clearly to system users. Alzahrani et al. (2017) found an effect of information quality on user satisfaction and Yadnya, et al (2019) found an effect of information quality on user satisfaction.

\subsection{Effect of Information Quality on Net Benefits}

The information quality variable has a positive path coefficient of 0.364 with a $p$ value of 0.000 ( $p$ value $<0.01$ ) which means that the sixth hypothesis (H6) is accepted. This proves that the quality of information generated by SISKEUDES has a positive effect on net benefits. The positive path coefficient means that the better the quality of information generated by SISKEUDES, the net benefits felt by individuals and organizations in implementing village financial management will increase. The existence of SISKEUDES launched by the BPKP and the Ministry of Home Affairs aims to help the performance of village officials in managing village finances so as to create a Good Governance Village as seen from the transparency and accountability of the management of the Village Government. The accountability report that is reported must also be in accordance with the applicable Laws and Government Regulations, SISKEUDES will automatically generate the various reports required, so that it will have a direct impact on saving time and costs, reducing the potential for fraud and errors, and assisting data aggregation, as well as increasing accountability. Accountability is carried out by the village government as the person responsible for the implementation of every activity / program that is carried out. Accountability to the district government is considered very important, because it is a prerequisite for the disbursement of village funds for the next stage. Based on the respondent's answer regarding the quality of information, on average the highest score is on the trustworthy indicator with the statement that the information produced by SISKEUDES is reliable. Therefore, the information generated by SISKEUDES does not need to be adjusted again to be given to parties who need the information. This will help accelerate the task of village financial managers and provide reliable information to stakeholders. Respondents' answers with the lowest scores on average are on accurate indicators so that it can be illustrated that the information generated by SISKEUDES sometimes changes data due to input errors or system errors so there is a need for supervision and assistance with DPMD or BPKP to integrate the system so that the information generated is appropriate. The results of the direct influence of information quality on net benefits are in accordance with the results of research by Ali et al. (2016) which found that the quality of information produced by the Accounting Information System in Jordan is a vital factor that can improve organizational performance. This occurs because 
the quality of information causes a reduction in operational cost activities that are outside the information processing system. High quality information in the context of information content (accuracy, completeness, relevance to decision making) can lead to higher organizational performance.

\subsection{Effect of Service Quality on Use}

The service quality variable has a positive path coefficient of 0.296 with a p value of 0.028 ( $p$ value $<0.05$ ), which means that the seventh hypothesis (H7) is accepted. This proves that user satisfaction has a positive effect on use. The positive path coefficient means that the higher the quality of services provided by DPMD or BPKP to system users, the more intense the use of the system will be. SISKEUDES is a product designed by the BPKP and the Ministry of Home Affairs to assist the performance of village managers and increase accountability at the Ministry level. The development of this system is carried out in stages from SISKEUDES 1.0 to SISKEUDES 2.0 with increased system services. The development of the application of SISKEUDES makes users need assistance and services when using the system. When problems occur when using the system, system users are given a contact person for the SISKUEDES section at DPMD as well as a village assistant who can be contacted immediately when a problem occurs with financial management or a problematic system. A quick solution will help users continue to use the system. The characteristics of the respondents describe the age of the majority of village financial managers in the Millennial Generation. This age is classified as having understood the use of technology, but there is a need for assistance when using SISKEUDES has problems. The shift from the use of simple systems to complex systems in 2016, so the implementation is still experiencing many difficulties. The important role of system developers, namely BPKP, is to help provide solution services when there are complaints / SISKEUDES problems. This assistance and service really helps users so that users find it easier to use and will increase their use of SISKEUDES. Others found that service quality has a positive effect on the use of SAIBA at the Lampung Ministry of Religion Office. This is due to the support and response from the BPKP when the system user apparatus experiences problems with SAIBA.

\subsection{Effect of Service Quality on User Satisfaction}

The service quality variable as a mediation for the effect of the system quality variable on net benefits has a positive path coefficient of 0.308 with a $p$ value of 0.002 ( $p$ value $<0.01$ ) which means that the eighth hypothesis (H8) is accepted. This proves that the quality of services provided by BPKP / DPMD affects the satisfaction felt by SISKEUDES users. The positive path coefficient means that the better the services provided by the BPKP / DPMD related to the SISKEUDES use solution, the more user perceived satisfaction will be. In accordance with the TPB, the support provided by the system provider will help give the user confidence that the system is easy to use and in accordance with the user's wishes or needs. Fulfilling user needs when using SISKEUDES can increase feelings of satisfaction with the system. The perception of SISKEUDES users on service quality shows that the system produced by BPKP is correct and in accordance with user needs, as well as providing fast responses to help SISKEUDES users. When a problem occurs, BPKP and DPMD provide good service and show an intention to help solve it. This optimal service from BPKP and DPMD is able to meet the needs of SISKEUDES users so that user satisfaction increases. This research is in line with the results of research by Hariwibowo and Wimpie (2020) who found that the services provided by BPKP to SISKEUDES users in Wonogiri were able to increase the satisfaction of using the system. Widiastuti et al. (2019) found that the good quality of BKD system services is able to meet user needs, so that user perceived satisfaction increases.

\subsection{Effect of Service Quality on Net Benefit}

The service quality variable on the net benefits has a positive path coefficient of 0.186 with a p value of 0.035 ( $p$ value $<0.05$ ), which means that the ninth hypothesis (H9) is accepted. This proves that the quality of services provided by BPKP / DPMD has an effect on net benefits. The path coefficient is positive, meaning that the higher the quality of the services provided, the more perceived net benefit the user feels. SISKEUDES is used by financial managers to increase accountability, reduce fraud and error in village financial processes. BPKP created this system because in 2015 there were still many accountability problems faced by the Village Government regarding reporting of Accountability Reports (LPJ) and Financial Reports that did not comply with applicable regulations. The implementation of SISKEUDES is a new system and began to be used in 2016 and was effective in 2017, so that assistance from BPKP or DPMD is needed so that SISKEUDES can be optimally used by the Village Government. SISKEUDES has been able to provide benefits to the performance of financial managers by producing accountable financial reports. This performance achievement cannot be separated from the attitude and quick response of the system developer to always help resolve complaints from SISKEUDES users. This research is in line with the results of research by Martins, et al. (2018) which found that a good system should ensure the existence of online help features, the existence of technical and user manuals, service availability, and also online information about how to use the system. This will increase the net benefits felt by system users. Azzara and Dudi (2020) also found that the service quality of the go-pay payment system affects the satisfaction of users of the system. 


\subsection{Effect of HR Quality on Use}

The HR quality variable has an influence on use with a positive path coefficient of 0.289 with a $p$ value of 0.002 ( $p$ value $>$ $0.01)$ which means that the ninth hypothesis (H10) is accepted. This proves that the quality of human resources from system users has an influence on use.

HR competence is one of the determinants of the successful use of the system. In accordance with positive cognitive theory which explains that the higher a person's self-efficacy or belief in his ability to organize and carry out actions, the easier it is to achieve set goals, and tries to assess levels and strengths across activities and contexts. The existence of intensive training is able to increase the interest of SISKEUDES users to use the system. Based on the average respondents' answers, it can be seen that the highest value related to the quality of human resources is training. Respondents perceived that they were already active in participating in training in Finance and operating SISKEUDES. This is able to increase the interest of village financial managers to want to use SISKEUDES. The number of times they attend training, the easier it is for respondents to use the system. The characteristics of the respondents in this study are the majority belonging to generation Y or millennial. This indicates that the quality of village financial management human resources is accustomed to using technology so that when required to use SISKEUDES, respondents have high intentions because they consider the system easy to use. This research is in line with the research of Wiguna et al. (2017) which found that the importance of the quality of human resources, training, education, and village assistants so that the use of the village financial system is more optimal.

\subsection{Effect of HR Quality on User Satisfaction}

The HR quality variable on user satisfaction has a negative path coefficient of -0.018 with a $p$ value of 0.419 ( $p$ value $>0.10$ ), which means that the eleven hypothesis (H11) is rejected. This proves that the quality of human resources owned by village financial managers has no effect on the satisfaction level of SISKEUDES users. The abilities possessed by users obtained from a training program should be able to make users feel more satisfied using the system because they can use and master the information system used. In this study, educational background, training, experience and understanding were not able to increase SISKEUDES user satisfaction. User satisfaction will increase when all the needs of the user are met. Based on the respondents' answers in this study, the lowest average value is related to the quality of human resources, namely education indicators. The education background of the respondent is not in accordance with the work in their field. In addition, the respondents' experience in the financial sector is lacking in this study. Therefore, inadequate education and experience in finance makes respondents unable to feel satisfied with the existing system. Although the existence of SISKEUDES has helped facilitate administration related to village fund management, it has not been able to provide a deep understanding of village finances. This causes input errors in SISKEUDES, as well as delays in depositing LPJ due to documents that do not comply with the Regulation of Minister of Home Affairs Regulation No. Therefore, more intensive assistance from BPKP / DPMD is required in the Village Government during the village APB management process, thereby reducing the possibility of input errors or shortages of LPJ Activity documents. This study is in line with Amhas' research (2018) which found that the quality of human resources was not able to affect the satisfaction of users of the Samsat system in Makassar due to the lack of training provided to employees.

\subsection{Effect of HR Quality on Net Benefit}

The HR quality variable on the net benefit has a positive path coefficient of 0.021 with a $p$ value of 0.375 ( $p$ value $>0.10$ ), which means that the twelve hypothesis (H12) is rejected. This proves that the quality of human resources owned by village financial managers has no effect on the net benefits felt by users. The quality of human resources cannot directly improve the performance of village officials. This is because SISKEUDES is made as simple as possible to manage village finances. The benefits of this system can be felt by system users regardless of the quality of human resources that users have, especially education and user experience in the financial sector. BPKP and the Ministry of Home Affairs launched this SISKEUDES to make it easier for financial managers to make planning and accountability reports according to the rules because before using SISKEUDES there were still many mistakes in making accountability reports or financial reports due to uneven human resources in the village. Millenium Pharmacon International Tbk when using the Millennium Pharmacon International (SIMPI) Information System Application was not able to improve the performance of the company's employees.

\subsection{Effect of Use on Net Benefit}

The use variable on the net benefits has a positive path coefficient of 0.271 with a $p$ value of 0.003 (p value $<0.01$ ) which means that the thirteenth hypothesis (H13) is accepted. This proves that the use of SISKEUDES has an effect on net benefits. The path coefficient is positive, meaning that the higher the user's interest in using SISKEUDES, the net benefit that the user feels will increase. The intensity of using the system indicates that the system can be optimally used. The more often the system is used, it is usually followed by the more degree of learning that users get regarding information systems (Mc Gill et al., 2003). The level of use of SISKEUDES in Badung Regency is already high. Respondents perceive the use of the system according to its use. The higher the intensity of using SISKEUDES, the village apparatus the more understanding and thorough the flow of financial management so as to minimize errors and fraud in the use of funds in the Village Government. The highest average respondents' answers regarding the use of SISKEUDES consider this system to be very helpful for employees 
in the Village Government in checking for financial process errors. Village financial management officials consider them to be more thorough in working on village financial transactions with SISKEUDES. The lowest average value related to the use of SISKEUDES is the intensity of use. Respondents did not spend any longer working time using SISKEUDES. This is because the respondents consist of the Head of Finance, and Operators, so that different job desks cause different intensities in using SISKEUDES. The results of this study are in line with the research of Yu and Siu (2018) who found that use has an influence on the net benefits of the EHR system in Australia. Dwirandra and Astika (2020) found the increasing usage behavior towards AIS, the more individual performance will be. This is very possible because by using SIA massively the work will be faster, more accurate, reduce repetition due to clerical errors, and of course the information is also more varied.

\subsection{The Effect of Satisfaction on Net Benefit}

The user satisfaction variable on the net benefits has a positive path coefficient of 0.142 with a $p$ value of 0.016 ( $p$ value $<0.05)$ which means that the fourteenth hypothesis $(\mathrm{H} 14)$ is accepted. This proves that SISKEUDES user satisfaction has an effect on net benefits. The path coefficient is positive, meaning that the higher the satisfaction felt by SISKEUDES users, the more the net benefits that users feel will increase. Information system user satisfaction has an impact not only on the individuals who use it, but also on the organizations that implement the information system. The higher the user satisfaction of the information system will have a positive impact on both the individual and the organization. On average, SISKEUDES users in Badung are satisfied with using SISKEUDES in managing village finances. SISKEUDES user satisfaction provides net benefits that have been felt by system users, such as being able to complete work more quickly and efficiently, as well as improving performance and accountability in managing village finances. Based on the respondent's answer regarding user satisfaction, on average the highest score is in the efficient indicator. This indicates that the use of SISKEUDES helps users in financial processes efficiently (saving time, effort, and costs) so that it makes it easier for users to complete their work quickly. The perception of satisfaction of SISKEUDES users directly has an impact on increasing individual performance as well as improving the performance of the Village government in Badung because financial reporting can be reported in an accountable, transparent and timely manner. The results of this study are in line with the research of Hariwibowo and Setiawan (2020) which found user satisfaction has a positive impact on improving the performance of village government employees in Wonogiri.

\section{Implications of Research Results}

This study proves that the modified DeLone and McLean model (2003) can be used as a mandatory (mandatory) system evaluation model. Previous research such as Gable et al., (2008) stated that use in the Delone McLean model cannot be used in the mandatory system, but in the journal Delone and Mclean (2016) states that use is still relevant for evaluating mandatory and voluntary systems. This study also proves that the use variable can affect the net benefits of users and is directly influenced by the variables of information quality, service quality and human resource quality. In addition, this study confirms the Theory Planned Behavior (TPB) in the use of the mandatory system. The results of this study indicate that the action to use the system, perceived user satisfaction and benefit perceptions are influenced by attitudes, subjective norms, and perceptions of behavioral control from the work environment, regulations, and user's self-competence.

\section{Research Limitations}

This research has been attempted and carried out in accordance with scientific procedures, however, it still has limitations, namely:

This research was only limited to the scope of one district. Research results will be more varied and develop well if the research is carried out in a broader scope considering that SISKEUDES has been used in almost all village governments in Indonesia. This study only uses a questionnaire in collecting data, so that it lacks in-depth information from the data obtained. In-depth information is needed because this system is related to government regulations and bureaucracy so that it will affect the results of research.

\section{Conclusion and suggestion}

Based on the results of the tests carried out in this study, it can be concluded that the quality of the system is not proven to have an effect on the use of SISKEUDES. The quality of the system has a positive effect on user satisfaction so that the better the quality of the village financial system the higher the user satisfaction of the system. The quality of the system is not proven to have an effect on the net benefits of SISKEUDES. The quality of information has a positive effect on the use of SISKEUDES, so that the better the quality of the information generated by SISKEUDES, it can increase the interest and intensity of using SISKEUDES. The better the quality of information generated from SISKEUDES, the user satisfaction in using SISKEUDES will increase. The better the quality of information generated by SISKEUDES, the higher the benefits perceived by users are. The better the quality of services provided by the BPKP and DPMD in assisting SISKEUDES users, the better the interest in using the system. The better the services provided by the BPKP and DPMD in assisting the use of SISKEUDES, 
the better the user satisfaction of the system. The better the quality of services provided by the BPKP and DPMD, the better the net benefits felt by SISKEUDES users. The better the quality of human resources owned by SISKEUDES users will provide an increase in the interest and intensity of using the system. The quality of human resources is not proven to have an effect on user satisfaction. The quality of human resources is not proven to have an effect on net benefits. The higher the interest and intensity of using SISKEUDES, it means that the system can be used optimally and will increase the net benefits that SISKEUDES users will experience. Increasing user satisfaction in using SISKEUDES can increase the net benefits that SISKEUDES users will experience. Based on the research results and conclusions above, the suggestions that can be given are as follows, namely based on the results of data tabulation, the SISKEUDES implemented in the Village Government is still classified as unstable and sometimes still experiences damage due to corrupted databases, damaged software or hardware. Therefore, the suggestion that can be given is that there is a need to increase the competence of village employees or operators from SISKEUDES in the IT field in order to overcome the damage to the database and the devices that support the use of the system. The information generated by SISKEUDES in the Village Government in Badung has low accuracy of information. This is because there are still inconsistencies between manual reports and reports produced by SISKEUDES. Suggestions that can be given to village financial managers, especially the SISKEUDES operator section, in order to increase understanding and knowledge regarding the use of SISKEUDES in managing village finances so that the data inputted is in accordance with the appropriate posts. Based on the tabulation of data, services and assistance provided by BPKP and DPMD are still deemed not fast enough to solve problems related to the use of SISKUEDES. This is due to the bureaucracy and complexity of the tasks of DPMD and BPKP so that they cannot immediately solve the problem of using SISKEUDES. Suggestions that can be given are for the Village Government to prepare one of its village employees in the IT department so that they can solve SISKEUDES problems when problems occur and coordinate with teams from BPKP and DPMD related to SISKEUDES. Based on the data tabulation, the educational qualifications possessed by SISKEUDES users are still not in accordance with the duties of the SISKEUDES financial manager in the Village Government. Therefore, it is hoped that DPMD and BPKP will conduct intensive training and mentoring related to village financial management and the use of SISKEUDES so that SISKEUDES users have adequate understanding to manage village finances. Satisfaction of SISKEUDES users in the Village Government in Badung is not yet optimal because there are still reports that are not provided in the SISKEUDES menu, for example quarterly reports on an offline system. In addition, the system used is still offline, even though SISKEUDES 2.2 can be used online so that it is integrated with OM SPAN. It is suggested to the village government to prepare human resources and supporting infrastructure so that the system can be implemented in Badung. The predictors of the success of the system assessment are not only seen from the system and the quality of users, but can also be seen from the influence of culture and the organizational environment that affects the application of the system. Future studies can use a wider sample so that it not only examines the success of system users in the Badung Village Government but can compare the use of SISKEUDES in Badung with other districts / cities in Bali Province. The next researcher can use the in-depth interview method with SISKEUDES user respondents or can use a questionnaire by adding suggestions in the distributed questionnaire.

\section{References}

Amhas, M. (2018). Pengaruh Kualitas Sumber Daya Manusia, Kualitas Pelayanan dan Kinerja Pegawai terhadap Kepuasan Pelanggan pada Kantor Sistem Administrasi Manunggal Satu Atap (Samsat) Makassar 01 Selatan. Jurnal Mirai Management, 3(1), 136-149.

Anggreni, N., Ariyanto, D., Suprasto, H., \& Dwirandra, A. (2020). Successful adoption of the village's financial system. Accounting, 6(6), 1129-1138. 10.5267/j.ac.2020.7.005.

Azzara, Z., \& Dudi, P. (2020). Analysis of the effect of system quality, information quality and service quality on user satisfaction information payment accounting information system using Delone \& Mclean methods (Case Study of Go-Pay Payment Services in the Go-Jek Application). e-Proceeding of Management, 7(2), 2817-2821.

Dinas Pemberdayaan Masyarakat Desa (DPMD) Kabupaten Badung. 2018. Laporan Pendampingan Desa Tahun 2018. 2019. Laporan Pendampingan Desa Tahun 2019

DeLone, W. H., \& McLean, E. R. (1992). Information systems success: The quest for the dependent variable. Information Systems Research, 3(1), 60-95.

DeLone, W. H., \& McLean, E. R. (2003). The DeLone and McLean model of information systems success: a ten-year update. Journal of Management Information Systems, 19(4), 9-30.

DeLone, W. H., \& McLean, E. R. (2016). Information systems success measurement. Foundations and Trends ${ }^{\circledR}$ in Information Systems, 2(1), 1-116.

Dirgantari, P. D., Hidayat, Y. M., Mahphoth, M. H., \& Nugraheni, R. (2020). Level of Use and Satisfaction of E-Commerce Customers in Covid-19 Pandemic Period: An Information System Success Model (ISSM) Approach. Indonesian Journal of Science and Technology, 5(2), 261-270.

Gable, G. G., Sedera, D., \& Chan, T. (2008). Re-conceptualizing information system success: The IS-impact measurement model. Journal of the Association for Information Systems, 9(7), 18.

Hariwibowo, I. N., \& Setiawan, W. Y. (2020). Evaluating the Implementation of the Rural Financial System (SISKEUDES) in Wonogiri Regency, Indonesia: Success or Failure?. Review of Integrative Business and Economics Research, 9, 101114.

Jin, T. F. (2002). Faktor-faktor yang mempengaruhi kinerja sistem informasi akuntansi. Jurnal Bisnis dan Akuntansi, 4(2), 135-154. 
Lee, E. Y., \& Jeon, Y. J. J. (2020). The Difference of user satisfaction and net benefit of a mobile learning management system according to self-directed learning: An investigation of cyber university students in hospitality. Sustainability, 12(7), 2672.

Lestari, E., \& Soesanto, O. R. C. (2020). Predicting factors that influence attitude to use and its implications on continues intention to use SVOD: Study on Netflix users of Indonesia. Jurnal Manajemen, 15(2), 183-208.

Martins, J., Branco, F., Gonçalves, R., Au-Yong-Oliveira, M., Oliveira, T., Naranjo-Zolotov, M., \& Cruz-Jesus, F. (2019). Assessing the success behind the use of education management information systems in higher education. Telematics and Informatics, 38, 182-193.

doi: https://doi.org/10.1016/j.tele.2018.10.001

Martono, S., NURKHIN, A., MUKHIBAD, H., ANISYKURLILLAH, I., \& WOLOR, C. W. (2020). Understanding the Employee's Intention to Use Information System: Technology Acceptance Model and Information System Success Model Approach. The Journal of Asian Finance, Economics and Business (JAFEB), 7(10), 1007-1013.

Noviyanti, N. (2016). Mengukur Kesuksesan Sistem Akuntansi Instansi Basis Akrual (SAIBA) Menggunakan Model Delone \& Mclean. Jurnal Tata Kelola dan Akuntabilitas Keuangan Negara, 2(2), 151-173.

Perry, W. E. (2006). Effective Methods for Software Testing. 3rd Edition. Indiana, Indianapolis: Wiley Publishing, Inc.

Peraturan Menteri Dalam Negeri Nomor 20 Tahun 2018 tentang pengelolaan keuangan desa.

Prianto, A. (2015). Dampak Dukungan Pimpinan, Pengalaman, Kemudahan dan Kemampuan Dalam Penggunaan KOmputer terhadap Keberhasilan Penggunaan Sistem Informasi SUmber Daya Manusia. Tesis. Jakarta : Universitas Bina Nusantara.

Purwanto, S. K., \& Suharno P. (2017). Pengaruh Kualitas Sistem, Kualitas Informasi, Dan Kualitas Layanan Terhadap Penggunaan Sistem E-Learning Di Program Pascasarjana Universitas Mercu Buana. Jurnal Manajemen, 21(2), $282-305$.

Rai, I. P. G. L., \& Suardikha, I. M. S. (2019). Analisis Kesuksesan SIPKAD Berdasarkan Model Delone \& McLean pada Sekretariat Daerah Kabupaten Buleleng. E-Jurnal Akuntansi Universitas Udayana, 29(2), $742-754$.

Rakhmawati, I., \& Siti, A. (2020). Kualitas Informasi Sistem Keuangan Desa Pasca Pengembangan Aplikasi. Jurnal Akuntansi Aktual, 4(2), 197-210

Sorongan, E., \& Qory H. (2020). Evaluation of Implementation E-Government with Delone and Mclean. Jurnal Ilmiah Penelitian dan Penerapan Teknologi Sistem Informasi, 14(1), 22-37.

Tilahun, M. (2019). A Review on Determinants of Accounting Information System Adoption. Science Journal of Business and Management, 7(1), 17-22.

Veeramootoo, N., Nunkoo, R., \& Dwivedi, Y. K. (2018). What determines success of an e-government service? Validation of an integrative model of e-filing continuance usage. Government Information Quarterly, 35(2), 161-174.

Widiastuti, R., Haryono, B.S., \& Said, A. (2019). Influence of System Quality, Information Quality, Service Quality on User Acceptance and Satisfaction and Ites Impact on Net Benefit (Study Study of Information System Users Lecturer Performance Load (BKD) in Malang State University). HOLISTICA-Journal of Business and Public Administration, 10(3), 111-132.

Wiguna, I. M. D. P. D., Yuniarta, G. A., Ak, S. E., \& Prayudi, M. A. (2018). Pengaruh Kualitas Sumber Daya Manusia, Pendidikan Dan Pelatihan, Serta Peran Pendamping Desa Terhadap Efektivitas Penggunaan Sistem Keuangan Desa (Siskeudes)(Studi Pada Desa Penerima Dana Desa Di Kabupaten Buleleng). JIMAT (Jurnal Ilmiah Mahasiswa Akuntansi) Undiksha, 8(2).

Yadnya, P., Suprasto, H. B., Dwirandra, A. A. N. B., \& Suaryana, I. G. N. A. 2019. Success implementation of online technology information system on market cooperative kumbasari denpasar. International Research Journal of Management, IT and Social Sciences, 6(6), 135-145. https://doi.org/10.21744/irjmis.v6n6.780 .www.bpkp.go.id. Diakses tanggal 12 Maret 2020.

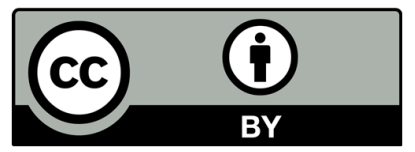

(C) 2021 by the authors; licensee Growing Science, Canada. This is an open access article distributed under the terms and conditions of the Creative Commons Attribution (CC-BY) license (http://creativecommons.org/licenses/by/4.0/). 